\title{
AN INVESTIGATION OF CHALLENGES FACED IN DETECTING FRAUDS
}

\author{
MS. BHAVNA SHARMA ${ }^{1} \&$ PROF. SULTAN SINGH ${ }^{2}$ \\ ${ }^{1}$ Research Scholar, Chaudhary Devi Lal University, Sirsa, Haryana \\ ${ }^{2}$ Department of Business Administration, Chaudhary Devi Lal University, Sirsa, Haryana
}

\begin{abstract}
Bank fraud is a worldwide phenomenon that saves no establishment and not even the economy. It is essential for banks to establish effective system to prevent and detect frauds so as to decrease the chances of frauds to take place. It is important to stop the fraud from happening in the first place. The detection of fraud comes after prevention as it includes recognizing fraud as fast as possible once it has been committed. The purpose of the study is to know the challenges faced by banks in detecting frauds. The data were collected through questionnaire filled from 120 bank staff, categorised into managers and officers, of Bank of India (BOI), Bank of Baroda (BOB), Axis Bank (AXIS) and ICICI Bank (ICICI) in the area of NCR. The collected data were analyzed with the help of various descriptive statistics like frequency distribution, mean, standard deviation, etc. To check the validity of the results and test the research hypotheses, t-test and Analysis of Variance (ANOVA) techniques were used. The results show that lack of customer alertness, non-submission of reports by the customers and non-sharing of information with others are the main challenges faced by banks in detecting frauds. To overcome the challenges of frauds, it is recommended that banks must be strict in verifying the reports being submitted by the customers and report the frauds to the concerned authority as and when occurred. There must be timely completion of internal and external audits at branch level.
\end{abstract}

KEYWORDS: Frauds, Detection, Training, Audit, Challenges, Prevention, Banks, Internal Control System

Received: Jun 08, 2020; Accepted: Jun 28, 2020; Published: Sep 15, 2020; Paper Id.: IJMPERDJUN20201129

\section{INTRODUCTION}

Fraud emerges when an individual or any association in position of trust and obligation purposely harms another individual or corporate. It is a worldwide phenomenon that saves no establishment and economy [1]. Bank fraud is the utilization of illegal means, to acquire cash or resources held or possessed by individual or corporate. All banks have an issue with deceitful borrowers [2]. Although banks are recognized as one of the most regulated segments; it is still a target for fraudsters [3]. The increasing fraud rate in banks is a genuine danger to their security, if it is not appropriately checked [4]. The frauds impose several costs to the banks and can be the cause of banking failure [3]. It might bring enormous money related misfortunes to banks, their clients, exhaustion of investors' assets and banks' capital base [4]. The bank might suffer financial loss, loss of reputation and exposure to the risk of bankruptcy [3]. Fraud adversely affect various cultural, economic and social dimensions. [5]. Banks are attempting new ways to detect and prevent frauds. In spite of the increased frequency of frauds and establishment of new anti-fraud laws, efforts are not very effective [6]. The most astonishing part is that banks take a very long time to perceive that there are casualties of a complex trap of deceit [4]. Prevention of frauds is a practical procedure since it is often hard to recover fraud losses, once they are recognised. The rise in fraud cases over a period of time shows that there is a strong need to enable the investigators and auditors to stop potential frauds [6]. It is essential for banks to establish effective system to prevent and detect frauds so as to decrease the chances of frauds to take place. Auditing only is 
not sufficient to detect and prevent the frauds. Rather, it is important to stop the fraud from happening in the first place. The detection of fraud comes after prevention as it includes recognizing fraud as fast as possible once it has been committed [7]. The knowledge of internal auditors helps in preventing and detecting frauds [8]. An effective internal control system helps in reducing the frauds [9]. The present study is conducted to know the challenges faced by the selected banks in detecting frauds.

\section{LITERATURE REVIEW}

Fraud is detected by employees, internal auditors and internal control system [10]. Robust internal control system is the most effective method of fraud prevention [11]. Reference check of employees, protecting password and whistle blowing policy must be adopted to prevent the frauds [6]. Attentiveness and innovativeness help in preventing frauds [12]. Frauds related to credit cards can be prevented by educating the customers [13]. Fraud detection methods are routine examination at all branches, reconciliation of accounts, periodic submission of statement of accounts, etc. [14]. The challenges faced by forensic auditors are lack of practical knowledge, lack of physical resources, interruption from management [15]. There is an association between customer alertness regarding fraud preventive measures and the quality of customer association [16]. Knowledge and skills of auditors helps in detecting the frauds [17]. Red flags help in detecting asset misappropriation [18]. Fraud finding softwares and customer alertness helps in reducing frauds [19]. Lack of fraud detecting tools, lack of alertness and resources are the main challenges in avoiding frauds [20]. Fraud in organizations is done by employees rather than customers [21]. Training of staff, regular auditing, staff rotation policy and reference check of employees are main fraud prevention techniques [3]. Rotation of auditors helps in reducing fraud [22]. Rotation of staff, reporting of frauds, improvement in internal control, operational audits, etc. are the effective ways of finding the frauds [7]. Document verification and reporting the fraud incidence helps in detecting the frauds [4]. Most of the frauds were spotted by customer grievances and by whistle blowing [23]. Major type of fraud is embezzlement of assets like cash thefts, stock theft, etc. [24]. Financial literacy, adequate remuneration and strengthening KYC norms helps in preventing frauds [25]. The challenges in detecting frauds were competition among the bank staff, job uncertainty, inadequate recruitment, poor internal control system and poor working environment [26]. Forensic accounting helps in prevention and detecting frauds [27]. Burden and enticement to commit fraud has a significance relationship with fraud occurrences in the Nigerian public sector [28]. Forensic accountants help in detecting frauds [29]. Internal system helps in detecting frauds [30]. Separation of duties and rotation of employees are the main fraud prevention techniques [31]. Profit Distribution Ratio do not have any effect on the fraud while Investment Ratio has an effect on the fraud [32]. The foregoing literature review shows that there is a need to conduct a study highlighting the challenges faced by banks in detecting frauds.

\section{RESEARCH OBJECTIVES}

The present study is conducted to know the challenges faced by the selected banks in detecting frauds and suggest the measures to overcome the challenges.

\section{Research Hypotheses}

To achieve the objectives and validate the results of the study, following research hypotheses were formulated:

$\mathbf{H}_{01}$ : There is no significant difference in the respondents' viewpoint towards the challenges faced in the detecting frauds by the selected public sector banks. 
$\mathbf{H}_{\mathbf{0 2}}$ : There is no significant difference in the respondents' viewpoint towards the challenges faced in the detecting frauds by the selected private sector banks.

$\mathbf{H}_{\mathbf{0 3}}$ : There is no significant difference in the respondents' viewpoint towards the challenges faced in the detecting frauds by the selected banks.

$\mathbf{H}_{\mathbf{0 4}}$ : There is no significant difference in the respondents' viewpoint towards the challenges faced in detecting frauds by the selected groups of banks.

\section{Sample Profile}

The population for the present study is all the public and private sector banks in India. But two public sector banks i.e. Bank of India (BOI) and Bank of Baroda (BOB) and two private sector banks i.e. Axis Bank (AXIS) and ICICI Bank (ICICI) have been chosen as a sample in this study. A sample of 120 respondents, categorised into managers (57), officers (63) i.e.30 each from each selected bank from the area of NCR was taken on the basis of purposive/snowball sampling. Out of total respondents, 74 (61.67 percent) were males and 46 (38.34 percent) were females. The numbers of the respondents with experience of less than 10 years were 89 (74.16 percent), 11 to 20 years were 12 (10 percent), 21 to 30 years were 13 (10.8 percent), and with 30 years or above were 6 (5 percent). Out of total respondents, 34 (28.33 percent) were graduates, 56 (46.67 percent) were post-graduates and 30 (25 percent) were professionally qualified.

\section{Data Collection}

Both types of data i.e. primary and secondary were used in the present study. Primary data were collected through a pretested structured questionnaire on five-point Likert scale i.e. Strongly Agree (SA), Agree (A), Neutral (N), Disagree (D) and Strongly Disagree (SD) to get response about the challenges faced by banks in detecting frauds during the period from July 2019 to January 2020. The secondary data were collected from journals, books, newspapers, websites, etc.

\section{Data Analysis}

The collected data have been analysed with the help of various descriptive techniques like frequency distribution, mean, standard deviation, etc. To check the validity of the results and test the hypothesis, t-test and ANOVA techniques were used.

\section{Reliability of the Scale}

Reliability of the instrument was checked by using Cronbach alpha. The reliability was 0.871 . Any value of 0.70 and above is a good measure of internal consistency. [33]

\section{RESULTS AND DISCUSSIONS}

The frequency distribution of the respondent's viewpoint towards the challenges faced by public sector banks in detecting frauds shows that most of the respondents agree/strongly agree towards non-sharing of information with others $(\mathrm{N}=44$, $\mathrm{P}=73.34)$, inadequate resources $(\mathrm{N}=36, \mathrm{P}=60)$, lack of staff alertness $(\mathrm{N}=37, \mathrm{P}=61.67)$, difficulty in assimilating data $(\mathrm{N}=35, \mathrm{P}=58.34)$, lack of customer alertness $(\mathrm{N}=43, \mathrm{P}=71.67)$, difficulty in examining crimes $(\mathrm{N}=40, \mathrm{P}=66.67)$, poor coordination with law execution agencies $(\mathrm{N}=36, \mathrm{P}=60)$, non-submission of reports by the customers $(\mathrm{N}=43, \mathrm{P}=71.67)$ and lack of synchronization among various banks $(\mathrm{N}=34, \mathrm{P}=56.67)$ while most of the respondents disagree/strongly disagree towards inadequate fraud discovery techniques $(\mathrm{N}=28, \mathrm{P}=46.67)$. 
Table-1 shows the descriptive and inferential statistics of the challenges faced in detecting frauds by the selected public sector banks. In BOI, difficulty in examining crimes $(\bar{x}=3.77, \sigma=1.006)$ is placed at the top, followed by lack of customer alertness $(\bar{x}=3.73, \sigma=0.980)$ and non-submission of reports by the customers $(\bar{x}=3.73, \sigma=1.081)$. However, in $\mathrm{BOB}$, non-sharing of information with others $(\overline{\mathrm{x}}=3.87, \sigma=0.819)$ is placed at the top, followed by lack of customer alertness $(\overline{\mathrm{x}}=3.80, \sigma=1.095)$ and non-submission of reports by the customers $(\overline{\mathrm{x}}=3.77, \sigma=0.817)$. Statistically, t-test results show that there is a significant difference in the respondents' viewpoint towards inadequate fraud discovery techniques $(p=0.005)$ at 5 percent level of significance in the selected banks, therefore the null hypothesis $\left(\mathrm{H}_{01}\right)$ i.e. there is no significant difference in the respondents' viewpoint towards the challenges faced in detecting frauds in the selected public sector banks, is rejected.

Table 1: Descriptive and Inferential Statistics in Public Sector Banks

\begin{tabular}{|l|c|c|c|c|c|c|c|c|}
\multicolumn{1}{|c}{ Statements } & \multirow{2}{*}{$\mathbf{N}$} & \multicolumn{2}{c|}{ BOI } & \multicolumn{2}{c|}{ BOB } & \multicolumn{2}{c|}{ t-test } \\
\cline { 6 - 9 } & & $\overline{\mathbf{x}}$ & $\boldsymbol{\sigma}$ & $\overline{\mathbf{x}}$ & $\boldsymbol{\sigma}$ & $\mathbf{t}$ & Sig \\
\hline Non-sharing of information with others & 60 & 3.40 & 1.429 & 3.87 & 0.819 & 1.552 & 0.126 \\
\hline Inadequate resources & 60 & 3.23 & 1.165 & 3.60 & 0.894 & 1.367 & 0.177 \\
\hline Lack of staff alertness & 60 & 3.53 & 0.937 & 3.50 & 1.009 & 0.133 & 0.895 \\
\hline Difficulty in integrating data & 60 & 3.40 & 1.192 & 3.20 & 1.126 & 0.668 & 0.507 \\
\hline Lack of customer alertness & 60 & 3.73 & 0.980 & 3.80 & 1.095 & 0.248 & 0.805 \\
\hline Inadequate fraud discovery techniques & 60 & 2.43 & 1.104 & 3.23 & 1.135 & 2.901 & $0.005^{*}$ \\
\hline Difficulty in examining crimes & 60 & 3.77 & 1.006 & 3.70 & 0.988 & 0.259 & 0.797 \\
\hline Poor coordination with law execution agencies & 60 & 3.43 & 1.278 & 3.53 & 1.042 & 0.332 & 0.741 \\
\hline Non-submission of reports by the customers & 60 & 3.73 & 1.081 & 3.77 & 0.817 & 0.135 & 0.893 \\
\hline Lack of synchronization among various banks & 60 & 2.63 & 1.217 & 3.40 & 0.968 & 0.128 & 0.899 \\
\hline
\end{tabular}

Note: N=No. of Respondents, $*=$ Significant at 5 percent level

Source: Primary survey (Author's Calculation)

The frequency distribution of the respondent's viewpoint towards the challenges faced by private sector banks in detecting frauds shows that most of the respondents agree/strongly agree towards non-sharing of information with others $(\mathrm{N}=36, \mathrm{P}=60)$, inadequate resources $(\mathrm{N}=32, \mathrm{P}=53.34)$, difficulty in assimilating data $(\mathrm{N}=27, \mathrm{P}=45)$, lack of customer alertness $(\mathrm{N}=36, \mathrm{P}=60)$, inadequate fraud discovery techniques $(\mathrm{N}=33, \mathrm{P}=55)$, difficulty in examining crimes $(\mathrm{N}=28$, $\mathrm{P}=46.67)$, poor coordination with law execution agencies $(\mathrm{N}=27, \mathrm{P}=45)$, non-submission of reports by the customers $(\mathrm{N}=38, \mathrm{P}=63.34)$ and lack of synchronization among various banks $(\mathrm{N}=25, \mathrm{P}=41.67)$ while most of the respondents disagree/strongly disagree towards lack of staff alertness $(\mathrm{N}=20, \mathrm{P}=33.34)$.

Table-2 shows the t-test results of the challenges faced by banks in detecting frauds by the selected private sector banks. In AXIS, non-sharing of information with others $(\bar{x}=3.73, \sigma=0.980)$ is placed at the top, followed by nonsubmission of reports by the customers $(\bar{x}=3.60, \sigma=1.102)$ and lack of customer alertness $(\bar{x}=3.50, \sigma=1.333)$ while in ICICI Bank, lack of customer alertness $(\bar{x}=3.73, \sigma=0.907)$ is placed at the top, followed by non-submission of reports by the customers $(\bar{x}=3.60, \sigma=1.070)$ and inadequate fraud discovery techniques $(\bar{x}=3.53, \sigma=1.042)$. Statistically, t-test results show that there is a significant difference in the respondents' viewpoint towards lack of synchronization among various banks $(p=0.010)$ at 5 percent level of significance in the selected private sector banks, therefore the null hypothesis $\left(\mathrm{H}_{01}\right)$ i.e. there is no significant difference in the respondents' viewpoint towards the challenges faced in detecting frauds in the selected private sector banks, is rejected. 
Table 2: Descriptive and Inferential Statistics in Private Sector Banks

\begin{tabular}{|l|c|c|c|c|c|c|c|}
\multicolumn{1}{|c}{ Statements } & \multirow{2}{*}{$\mathbf{N}$} & \multicolumn{2}{c|}{ AXIS } & \multicolumn{2}{c|}{ ICICI } & \multicolumn{2}{c|}{ T-Test } \\
\cline { 7 - 9 } & & $\overline{\mathbf{X}}$ & $\mathbf{\Sigma}$ & $\overline{\mathbf{X}}$ & $\mathbf{\Sigma}$ & $\mathbf{T}$ & Sig \\
\hline Non-sharing of information with others & 60 & 3.73 & 0.980 & 3.37 & 1.497 & 1.122 & 0.266 \\
\hline Inadequate resources & 60 & 3.27 & 1.258 & 3.47 & 1.137 & 0.646 & 0.521 \\
\hline Lack of staff alertness & 60 & 3.03 & 1.129 & 3.17 & 1.206 & 0.442 & 0.660 \\
\hline Difficulty in integrating data & 60 & 3.17 & 1.117 & 3.20 & 1.064 & 0.118 & 0.906 \\
\hline Lack of customer alertness & 60 & 3.50 & 1.333 & 3.73 & 0.907 & 0.793 & 0.431 \\
\hline Inadequate fraud discovery techniques & 60 & 3.17 & 1.177 & 3.53 & 1.042 & 1.278 & 0.206 \\
\hline Difficulty in examining crimes & 60 & 3.23 & 1.194 & 3.40 & 1.133 & 0.555 & 0.581 \\
\hline Poor coordination with law execution agencies & 60 & 3.13 & 1.137 & 3.37 & 1.189 & 0.777 & 0.440 \\
\hline Non-submission of reports by the customers & 60 & 3.60 & 1.102 & 3.60 & 1.070 & 0.000 & 1.000 \\
\hline Lack of synchronization among various banks & 60 & 3.40 & 1.133 & 2.60 & 1.192 & 2.665 & $0.010 *$ \\
\hline
\end{tabular}

Note: $\mathrm{N}=$ No. of Respondents *=Significant at 5 percent level

Source: Primary survey (Author's Calculation)

Table-3 shows the descriptive and inferential statistics of the challenges faced in detecting frauds by the selected banks. In BOI, difficulty in examining crimes $(\bar{x}=3.77, \sigma=1.006)$ is placed at the top, followed by lack of customer alertness $(\bar{x}=3.73, \sigma=0.980)$ and non-submission of reports by the customers $(\bar{x}=3.73, \sigma=1.081)$. In BOB, non-sharing of information with others $(\bar{x}=3.87, \sigma=0.819)$ is placed at the top, followed by lack of customer's alertness $(\bar{x}=3.80, \sigma=1.095)$ and non-submission of reports by the customers $(\overline{\mathrm{x}}=3.77, \sigma=0.817)$. In AXIS, non-sharing of information with others $(\overline{\mathrm{x}}=3.73, \sigma=0.980)$ is placed at the top, followed by non-submission of reports by the customers $(\overline{\mathrm{x}}=3.60, \sigma=1.102)$ and lack of customer alertness $(\bar{x}=3.50, \sigma=1.333)$. In ICICI, lack of customer alertness $(\bar{x}=3.73, \sigma=0.907)$ is placed at the top, followed by non-submission of reports by the customers $(\overline{\mathrm{x}}=3.60, \sigma=1.07)$ and inadequate fraud discovery techniques $(\overline{\mathrm{x}}=3.53, \sigma=1.042)$. As a whole, lack of customer alertness $(\overline{\mathrm{x}}=3.69, \sigma=1.083)$ is placed at the top, followed by nonsubmission of reports by the customers $(\bar{x}=3.68, \sigma=1.041)$ and non-sharing of information with others $(\bar{x}=3.59, \sigma=1.220)$. The mean score of all the statements is more than 3.00, which shows that most of the respondents agree with the challenges faced by banks in detecting frauds. Statistically, ANOVA results show that there is a significant difference in the respondents' viewpoint towards the inadequate fraud discovery techniques $(p=0.002)$ and lack of synchronization $(p=0.004)$ among various banks at 5 percent level of significance in the selected banks, therefore the null hypothesis $\left(\mathrm{H}_{01)}\right.$ i.e. there is no significant difference in the respondents' viewpoint towards the challenges faced in detecting frauds in the selected banks, is rejected.

Table 3: Descriptive and Inferential Statistics in Selected Banks

\begin{tabular}{|l|c|c|c|c|c|c|c|c|c|c|c|c|c|}
\hline \multicolumn{1}{|c|}{ Statements } & \multirow{2}{*}{$\mathbf{N}$} & \multicolumn{2}{|c|}{ BOI } & \multicolumn{2}{c|}{ BOB } & \multicolumn{2}{c|}{ AXIS } & \multicolumn{2}{c|}{ ICICI } & \multicolumn{2}{c|}{ Total } & \multicolumn{2}{c|}{ ANOVA } \\
\hline $\begin{array}{l}\text { Non-sharing } \\
\text { of } \\
\text { information } \\
\text { with others }\end{array}$ & 30 & 3.40 & 1.429 & 3.87 & 0.819 & 3.73 & 0.980 & 3.37 & 1.497 & 3.59 & 1.220 & 1.238 & 0.299 \\
\hline $\begin{array}{l}\text { Inadequate } \\
\text { resources }\end{array}$ & 30 & 3.23 & 1.165 & 3.60 & 0.894 & 3.27 & 1.258 & 3.47 & 1.137 & 3.39 & 1.117 & 0.713 & 0.546 \\
\hline $\begin{array}{l}\text { Lack of staff } \\
\text { alertness }\end{array}$ & 30 & 3.53 & 0.937 & 3.50 & 1.009 & 3.03 & 1.129 & 3.17 & 1.206 & 3.31 & 1.083 & 1.583 & 0.197 \\
\hline $\begin{array}{l}\text { Difficulty in } \\
\text { integrating } \\
\text { data }\end{array}$ & 30 & 3.40 & 1.192 & 3.20 & 1.126 & 3.17 & 1.117 & 3.20 & 1.064 & 3.24 & 1.115 & 0.270 & 0.847 \\
\hline $\begin{array}{l}\text { Lack of } \\
\text { customer } \\
\text { alertness }\end{array}$ & 30 & 3.73 & 0.980 & 3.80 & 1.095 & 3.50 & 1.333 & 3.73 & 0.907 & 3.69 & 1.083 & 0.437 & 0.727 \\
\hline
\end{tabular}




\begin{tabular}{|l|l|l|l|l|l|l|l|l|l|l|l|l|l|}
\hline $\begin{array}{l}\text { Inadequate } \\
\text { fraud } \\
\text { discovery } \\
\text { techniques }\end{array}$ & 30 & 2.43 & 1.104 & 3.30 & 1.208 & 3.17 & 1.177 & 3.53 & 1.042 & 3.11 & 1.194 & 5.255 & $0.002^{*}$ \\
\hline $\begin{array}{l}\text { Difficulty in } \\
\text { examining } \\
\text { crimes }\end{array}$ & 30 & 3.77 & 1.006 & 3.70 & 0.988 & 3.23 & 1.194 & 3.40 & 1.133 & 3.53 & 1.092 & 1.615 & 0.190 \\
\hline $\begin{array}{l}\text { Poor } \\
\text { coordination } \\
\text { with law } \\
\text { execution } \\
\text { agencies }\end{array}$ & 30 & 3.43 & 1.278 & 3.53 & 1.042 & 3.13 & 1.137 & 3.37 & 1.189 & 3.37 & 1.159 & 0.639 & 0.591 \\
\hline $\begin{array}{l}\text { Non- } \\
\text { submission of } \\
\text { reports by the } \\
\text { customers }\end{array}$ & 30 & 3.73 & 1.081 & 3.77 & 0.817 & 3.60 & 1.102 & 3.60 & 1.070 & 3.68 & 1.014 & 0.220 & 0.882 \\
\hline $\begin{array}{l}\text { Lack of } \\
\text { synchronizati } \\
\text { on among } \\
\text { various banks }\end{array}$ & 30 & 3.50 & 1.075 & 3.47 & 0.937 & 3.40 & 1.133 & 2.60 & 1.192 & 3.24 & 1.138 & 4.680 & $0.004 *$ \\
\hline
\end{tabular}

Note: $\mathrm{N}=$ No. of Respondents, ${ }^{*}=$ Significant at 5 percent level

Source: Primary survey (Author's Calculation)

Table-4 shows the descriptive and inferential statistics of the challenges faced in detecting frauds by the selected public and private sector banks. In public sector banks, lack of customer alertness $(\bar{x}=3.77, \sigma=1.031)$ is placed at the top, followed by non-submission of reports by the customers $(\bar{x}=3.75, \sigma=0.950)$ and difficulty in examining crimes $(\bar{x}=3.73$, $\sigma=0.989)$ and lack of customer alertness $(\bar{x}=3.62, \sigma=1.136)$ is placed at the top, followed by non-submission of reports by the customers $(\bar{x}=3.60, \sigma=1.077)$ and non-sharing of information with others $(\bar{x}=3.55, \sigma=1.268)$ in private sector banks. The mean score of all the statements is more than 3.00, which shows that most of the respondents agree with the challenges faced by banks in detecting frauds. Statistically, the results of t-test show that there is a significant difference in the respondents' viewpoint towards the Lack of staff alertness $(p=0.035)$, Inadequate fraud discovery techniques $(p=0.015)$, difficulty in examining crimes $(p=0.036)$ and Lack of synchronization among various banks $(p=0.036)$ at 5 percent level of significance in the selected groups of banks, therefore the null hypothesis $\left(\mathrm{H}_{04}\right)$ i.e. there is no significant difference in the respondents' viewpoint towards the challenges faced in detecting frauds by the selected groups of banks, is rejected.

Table 4: Descriptive and Inferential Statistics in Public and Private Sector Banks

\begin{tabular}{|c|c|c|c|c|c|c|c|}
\hline \multirow{2}{*}{ Statements } & \multirow[t]{2}{*}{$\mathbf{N}$} & \multicolumn{2}{|c|}{$\begin{array}{c}\text { Public Sector } \\
\text { Banks }\end{array}$} & \multicolumn{2}{|c|}{$\begin{array}{c}\text { Private } \\
\text { Sector Banks }\end{array}$} & \multicolumn{2}{|c|}{ T-Test } \\
\hline & & $\overline{\mathbf{X}}$ & $\Sigma$ & $\overline{\mathbf{X}}$ & $\Sigma$ & $\mathbf{T}$ & Sig \\
\hline Non-sharing of information with others & 60 & 3.63 & 1.178 & 3.55 & 1.268 & 0.373 & 0.710 \\
\hline Inadequate resources & 60 & 3.42 & 1.046 & 3.37 & 1.193 & 0.244 & 0.808 \\
\hline Lack of staff alertness & 60 & 3.52 & 0.965 & 3.10 & 1.160 & 2.139 & $0.035^{*}$ \\
\hline Difficulty in integrating data & 60 & 3.30 & 1.154 & 3.18 & 1.081 & 0.571 & 0.569 \\
\hline Lack of customer alertness & 60 & 3.77 & 1.031 & 3.62 & 1.136 & 0.757 & 0.450 \\
\hline Inadequate fraud discovery techniques & 60 & 2.83 & 1.181 & 3.35 & 1.117 & 2.461 & $0.015^{*}$ \\
\hline Difficulty in examining crimes & 60 & 3.73 & 0.989 & 3.32 & 1.157 & 2.120 & $0.036^{*}$ \\
\hline Poor coordination with law execution agencies & 60 & 3.48 & 1.157 & 3.25 & 1.159 & 1.104 & 0.272 \\
\hline Non-submission of reports by the customers & 60 & 3.75 & 0.950 & 3.60 & 1.077 & 0.809 & 0.420 \\
\hline Lack of synchronization among various banks & 60 & 3.02 & 1.157 & 3.50 & 1.112 & 2.333 & $0.021 *$ \\
\hline
\end{tabular}

Note: $\mathrm{N}=$ No. of Respondents, *=Significant at 5 percent level

Source: Primary survey (Author's Calculation) 


\section{CONCLUSIONS AND RECOMMENDATIONS}

Fraud has an adverse effect on the performance of Indian banking sector. The results of the study show that the main challenges faced by banks in detecting frauds are lack of customer alertness, non-submission of reports by the customers and non-sharing of information with others. In cases of frauds related to consortium finance, it has been observed that bank does not provide information to other banks, so the system of consortium lending has to be improved. The bank staff and customers must be educated regarding frauds. They must be strict in verifying the reports being submitted by the customers and report the frauds to the concerned authority as and when occurred. There must be timely completion of internal and external audits at branch level. The auditors must be held accountable in case the fraud is not detected by them and should work as a team and not in silos. There must be a proper check in finding the weaknesses in the internal control system. The banks must advance the outdated practices to a modern one.

\section{Implications of the Study}

This study aims to bring light on the challenges faced by banks in detecting frauds. The study will contribute to a more effective ways to detect the frauds in the banking sector. It will also help in framing the policies and strategies for detecting frauds. The study will provide a base to the future researchers to conduct the research in this area and contribute to the existing literature on frauds in banking sector.

\section{Limitations and Further Scope of Research}

The present study is limited to four banks only. So, the future study may comprise other public sector and/or private banks to attain more concrete results. The study may also be done in other parts of nation as this study is restricted to NCR area. The other aspects like reasons of frauds, types of frauds, impact of frauds on the performance of the banks, etc. may also be examined by the researchers.

\section{REFERENCES}

1. Adetoso, A. J., \& Akinselure. O. (2016). Fraud Control and Fraud Prevention in Nigeria Banking Industry. International Journal of Research in Finance and Marke ting, 6(12), 66-83. Retrieved on Decemeber 20, 2018.

2. Metawa, N. E. (2019). Expert Systems in Finance: Smart Financial Applications in Big Data Environments (1st ed.). Routledge. Retrieved on February 18, 2020, from https://books. google. co.in/books.

3. Rahman, R. A. (2014). Effectiveness of Fraud Prevention and Detection Techniques in Malaysian Islamic Banks. Procedia - Social and Behavioral Sciences, 145, 97-102.doi: 10.1016/j.sbspro.2014.06.015.

4. Sanusi, Z. M., Rameli, M. F., \& Isa, Y. M. (2015). Fraud Schemes in the Banking Institutions: Prevention Measures to Avoid Severe Financial Loss. Procedia Economics and Finance, 28, 107-113. doi:https://doi.org/10.1016/S2212-5671(15)01088-6.

5. Nafchi, A.R. \& Dastgir, M. (2020). Identification and Ranking of the Risk Factors Affecting the Probability of Occurrence of Fraud in Banks (A Case Study: An Iranian Bank), Journal of Critical Reviews,7(2),2020. http://dx.doi.org/10.31838/jcr.07.02. 36.

6. Bierstaker, J. L. (2006). Accountants' Perceptions Regarding Fraud Detection and Prevention Methods. Managerial Auditing Journal, 21(5), $520-535$.

7. Othmana, R. A. (2015). Fraud Detection and Prevention Methods in the Malaysian Public Sector: Accountants' and Internal Auditors' Perceptions. Procedia Economics and Finance, 28, 59-67. doi: 10.1016/S2212-5671(15)01082-5.

8. Macailao, M.C. (2020). Strategic Approaches of Internal Auditors on Occupational Fraud, Journal of Critical Reviews, 7(11), 2020. DOI: http://dx.doi.org/10.31838/jcr.07.11.05.

9. Ali, M.M., Ayop, N.F., Ghani, E.K. \& Hasnan, S. (2020). The Effect of Employees' Perceptions on Internal Control System Mechanisms 
Towards Employee Fraud Prevention, Journal of Critical Reviews, 7(18), 2020.

10. Bishop, T. (2004). Preventing, Deterring, and Detecting Fraud: What Works and What Doesn't, Journal of Investment Compliance, 5 (2), 120 - 127. http://dx.doi.org /10.1108/15285810410636073.

11. Seetharaman, A., Senthilvelmurugan, M. \& Periyanayagam, R. (2004). Managerial Auditing Journal, 19 (8), 1055-1072. DOI 10.1108/02686900410557953.

12. Coburn, N.F. (2006), Corporate investigations, Journals of Financial Crime, 13 (3), 348-368.

13. Williams, D. A. (2007), Credit card fraud in Trinidad and Tobago, Journal of Financial Crime,14 (3), 340359. https://doi.org/10.1108/13590790710758521.

14. Mahdi, S.\& Zhila, A. (2008). Fraud Detection and Audit Expectation Gap: Empirical from Iranian Bankers. International Journal of Business and Management, 3(10), 65-67.

15. Njanike, K., Dube, T., \& Mashayanye, E. (2009). The Effectiveness of Forensic Auditing in Detecting, Investigating, and Preventing Bank Frauds. Journal of Sustainable Development in Africa, 10(4), 405-425.

16. Hoffmann, A. O., \& Birnbrich, C. (2012). The Impact of Fraud Prevention on Bank-Customer Relationships: An Empirical Investigation in Retail Banking. International Journal of Bank Marketing, 30(5), 390-407. doi:http://dx.doi.org/10.1108/0265232121 1247435.

17. Josiah, M., Samson, A. A. \& Elizabeth, A. O. (2012). Evaluation of Roles of Auditors in the Fraud Detection and Investigation in Nigerian Industries. American Journal of Social and Management Sciences, 3(2), 49-59. doi:10.5251/ajsms.2012.3.2.49.59.

18. Gullkvist, B.\& Jokipii, A. (2013). Perceived Importance of Red Flags Across Fraud Types. Critical Perspective on Accounting, 24, 44-61.

19. Usman, A. K. \& Shah, M. H. (2013). Critical Success Factors for Preventing E-Banking Fraud. Journal of Internet Banking and Commerce, $18(2), 1-15$.

20. Dzomira S. (2014). Electronic Fraud (Cyber Fraud) Risk in the Banking Industry, Zimbabwe, Risk Governance \& Control: Financial Markets \&Institutions, 4(2),16-26.

21. Kroll, (2014) Global Fraud Report 2013/2014, Economist Intelligence Unit, Available at: http://fraud.kroll.com/wp-content/uploads /2013/10/ Global Fraud Report_2013-14_WEB.pdf [Accessed 25/11/2014].

22. Gupta, P. \& Gupta, S. (2015). Corporate Frauds in India - Perceptions and Emerging Issues, Journal of Financial Crime, 22 (1), $79-103$. http://dx.doi.org/10.1108/JFC-07-2013-0045

23. Bhasin, M. L. (2016). Combatting Bank Frauds by Integration of Technology: Experience of a Developing Country. British Journal of Research, 3(3).200-212.

24. Omar, M., Nawawi, A. \& Puteh Salin, A.S.A. (2016). The Causes, Impact and Prevention of Employee Fraud: A Case Study of an Automotive Company, Journal of Financial Crime, 23 (4) 1012-1027. https://doi.org/10.1108/JFC-04-2015-0020.

25. Singh, C. (2016). Frauds in the Indian Banking Industry. Working Paper, IIMB, WP NO. 505, March 2016.

26. Badejo, B.A., Okuneye, B.A \& Taiwo, M.R (2017). Fraud Detection in the Banking System in Nigeria Challenges and Prospects, Journal of Economics and Business, 2 (3), 255-282.

27. Ejoh, N.O. (2017) Forensic Accounting, Internal Controls and Fraudulent Practices in Nigeria, Scholars Journal of Economics, Business and Management, 4(8B), 555-562.

28. Abdullahi, R., \& Mansor, N. (2018). Fraud Prevention Initiatives in the Nigerian Public Sector: Understanding the Relationship of Fraud Incidences and the Elements of Fraud Triangle Theory. Journal of Financial Crime, 25 (4), 1-18. https:// doi.org/10.1108/JFC-02-2015-0008.

29. Oyebisi, O., Wisdom, O., Olusogo, O., \& Ifeoluwa, O. (2018). Forensic Accounting and Fraud Prevention and Detection in Nigerian Banking Industry. COJ Reviews \& Research, 1(1), 1-8.

30. Purnamasari, P., Arezona, S.N., Lestira, M. \& Maemunah, M. (2018). The Effect of Internal Auditor on Four Main Pillars in Fighting Fraud, International Journal of Management and Applied Science, 4 (3)26-30. 
31. Repousis, S., Lois, P., \& Veli, V. (2019). An investigation of the fraud risk and fraud scheme methods in Greek commercial banks. Journal of Money Laundering Control, 22 (1), 53-61. doi:https://doi.org/10.1108/JMLC-11-2017-0065.

32. Hamzah, Aripin, A. \& Aulia, R. (2020). The Factors That Influences of The Fraud in Syariah Bank, Journal of Critical Reviews, 7(1), 2020.

33. Nunnally, J. C. (1978). Psychometric Theory. McGraw-Hill Book Company, 86-113, 190-255. 

